\title{
IMPLICATIONS OF HIGHWAY CAPACITY MANUAL ON FREEWAY MEASURE OF EFFECTIVENESS: A CASE STUDY
}

\author{
Mohammad M Molla ${ }^{1}$ \\ ${ }^{1}$ Graduate Research Assistant, Department of Civil and Environmental Engineering, North Dakota State University, \\ North Dakota, USA
}

\begin{abstract}
The Fargo-Moorhead Metropolitan Area's rapid population and employment annual growth rate of 2.5 percent leading an opportunity for transportation infrastructure development. The forecasted growth will add demand, new number of trips, persons, vehicles, and vehicle hour travel, vehicle miles travel in the two principal Interstates (I-29 and I-94) in the Fargo-Moorhead Metropolitan Area. Consequentially, due to the increasing demand, interstates planning performance could be affected significantly in this area and will increase congestion, and thus, require a study with measuring of effectiveness in planning context. Therefore, a study of interstate within the Fargo-Moorhead metro area will be performed with measuring the deficiencies of several parameters such as volume, capacity, and level of service. The study will identify and provide guidance on congested areas incurred due to the forecasted/induced travel demand.
\end{abstract}

Key Words: Interstate Operational Analysis, I-29 Corridor, I-94 Corridor, Travel Demand, and MPO

\section{INTRODUCTION}

\subsection{Overview}

The Fargo-Moorhead Metropolitan Planning Area (MPA) lies in two counties, which is Cass County in North Dakota and Clay County in Minnesota and 15 cities (Fargo, West Fargo, Horace, Kindred, Mapleton, Casselton, Harwood, Argusville, Oxbow Cities in North Dakota and Moorhead, Dilworth, Sabin, Glydin, Hawley, Barnesville Cities in Minnesota). According to US Census 2010, this MPA population was 187,587 (Ulteigh and McKibben Demographics Research, 2012). Since the current population is more than two hundreds thousands, according to (Transportation Research Board, 2012), this MPA could be designated as medium size MPA. In this medium size MPA; Fargo is one of the largest cities which hold 105,549 populations (more than 56 percent). According to 2014 long range transportation plan, more than $95 \%$ of the workers who lives in Cass and Clay counties works within Cass and Clay county. The majority of the commuting working pattern for this MPA is within the MPA.

Based on Federal Functional Classification System (Federal Highway Administration, 2015) and (Fargo-Moorhead Metropolitan Council of Governments, 2014), Interstates 29 and 94 displayed in Figure 1 are the two major principal interstates/facilities that could support the radial commuting pattern for this regional travel within the region and MPA (Fargo-Moorhead Metropolitan Council of Governments, 2014). Beside this commuting, the interstate I-29 north connect the Winnipeg in Canada, I-29 south connect to Brookings in South Dakota, I-94 east connect to Minneapolis in Minnesota, and I-94 west connect to Billings in Montana. These two interstates are serving as the major mode for peoples, goods and freight movement. There are more than 200 interstate lane miles, which is more than $6.5 \%$ of total lanes miles of this MPA. These interstate facilities are being using approximately $18 \%$ of total daily vehicle miles traveled.

The existing travel demand model replicate very reasonably the daily total vehicle miles travel especially for the interstate facility. The model 2010 also included a base year scenario for the year 2010. Since the study area's transportation system would be affected to meeting the future growth, interstate facilities may become congested. Travel demand planning model utilize highway capacity manual (HCM) to validate it's forecasting power. HCM 2010 and 2000 may lead to significant difference in measuring the level of service and volume-capacity ratio. Forecasting for 2010 in base year 2000 with HCM 2000 might be different if HCM 2010 is used. Even though the level of services is relative to each location and methods of selection, for a same location it may produce two different results.

Therefore, this study will first measure the effectiveness/ performance of the interstate facilities considering the base year condition 2010 and will provide guidance for stakeholders, and will study the implications of highway capacity manual 2000 and 2010 based on planning model approach.

\subsection{Problem Statement}

There are more than 200 interstate lane miles, which is more than $6.5 \%$ of total lanes miles of the Fargo-Moorhead Metro Area. The interstate facilities are being using approximately $18 \%$ of total daily vehicle miles traveled based on the existing travel demand model developed for the base year 2010. The existing travel demand model replicate very 
reasonably the daily total vehicle miles travel especially for the interstate facility. Since the study area's transportation system would be affected to meeting the future growth, interstate facilities may become congested. Therefore, this study will measure the effectiveness/performance of the interstate facilities considering the base year condition 2010 , and will provide guidance for stakeholders, and will study the implications of highway capacity manual 2000 and 2010 based on planning model approach.

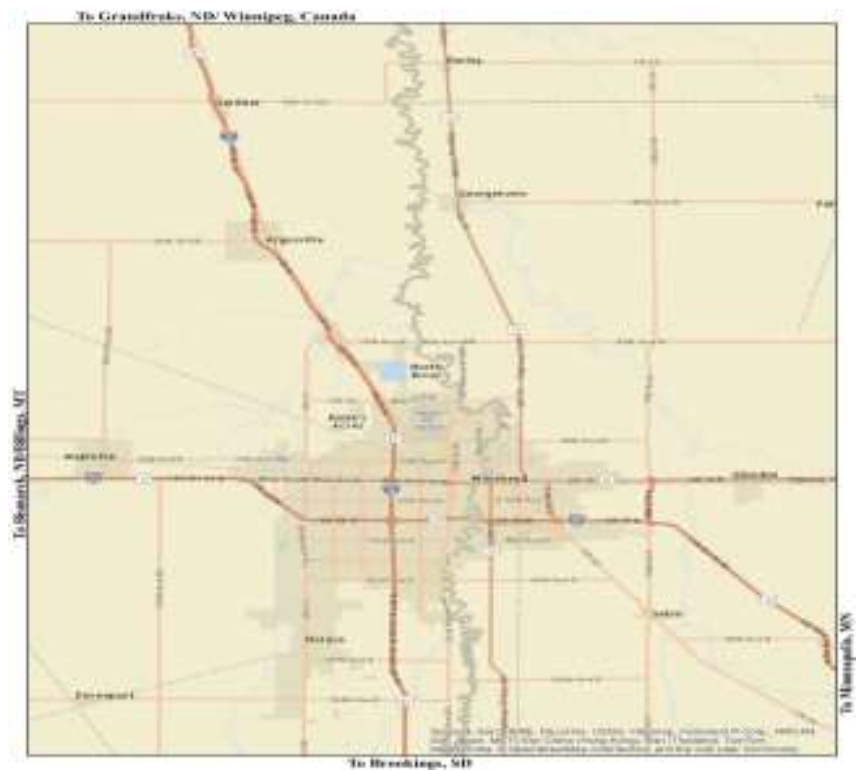

Fig -1: Interstates Facilities in the Fargo-Moorhead Metropolitan Area

\subsection{Objective}

This study will perform a case study with I-94 Eastbound principal Interstate in the Fargo-Moorhead Metropolitan Area. The study will identify and provide guidance on congested areas on the freeway facilities incurred based on future demand. The study will include the areas with deficiencies in volume, capacity and level of services that need to be improved towards meeting the demand. Finally, the study will compare the implications of highway capacity manual 2000 and 2010.

\section{DATA COLLECTION, MODEL AND METHODOLOGY}

\subsection{Study Area}

This study area was limited to only Fargo-Moorhead Metropolitan Area, which has been presented in Figure 2. The study area included interstates I-94 Eastbound. The twenty two miles I-94 interstate in the study area has 13 interchanges.

Eastbound of interstate I-94 was divided into total 33 roads segments, which is presented in Figure 3. There were also 16 off-ramps and 14 on-ramps on the 13 interchanges of the eastbound of I-94 included in the studies. The details of ramp locations are presented in Table 1.

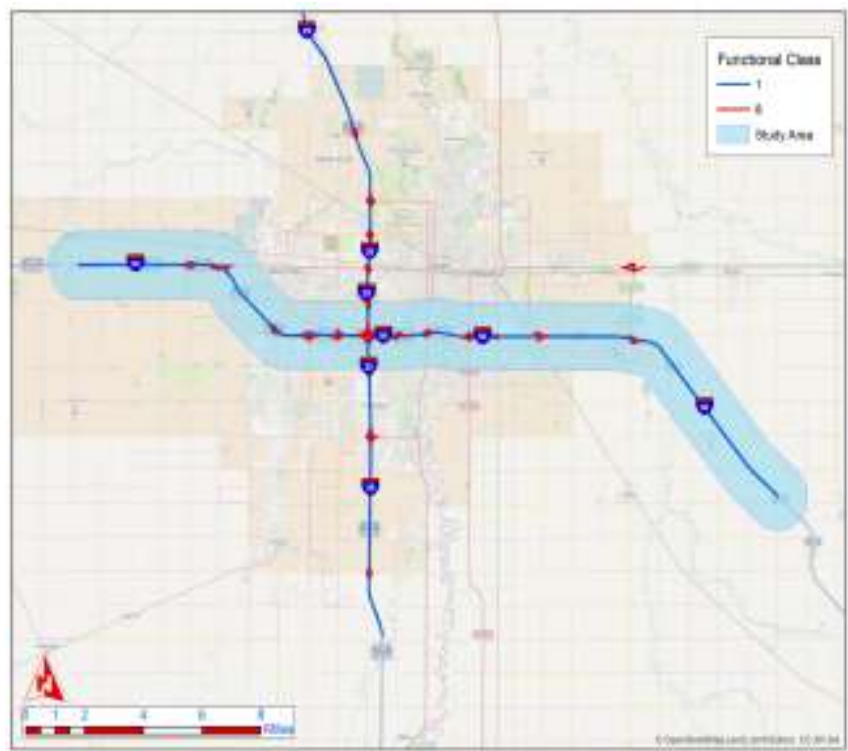

Fig -2: Study Location

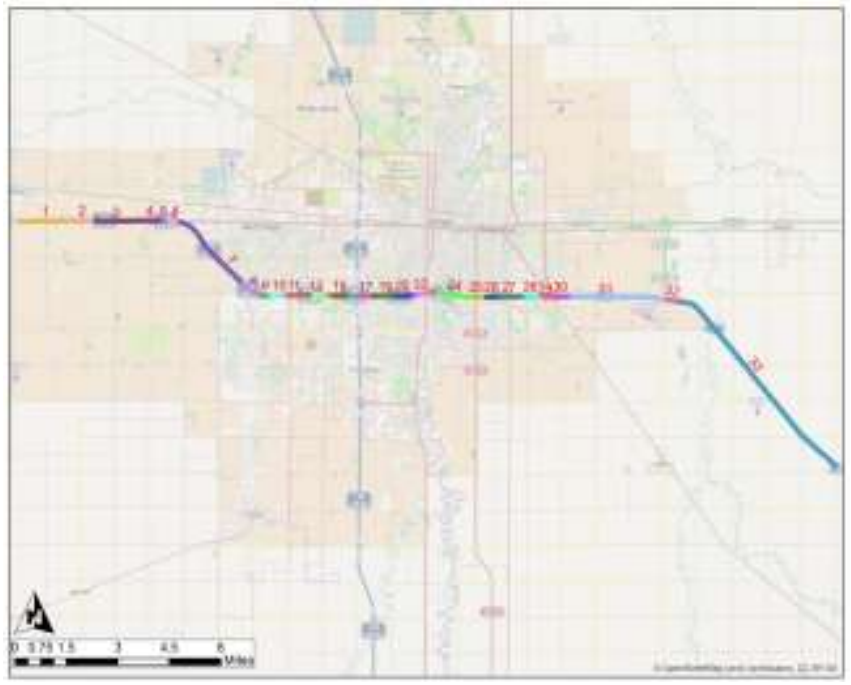

Fig -3: I-94 Eastbound Segments

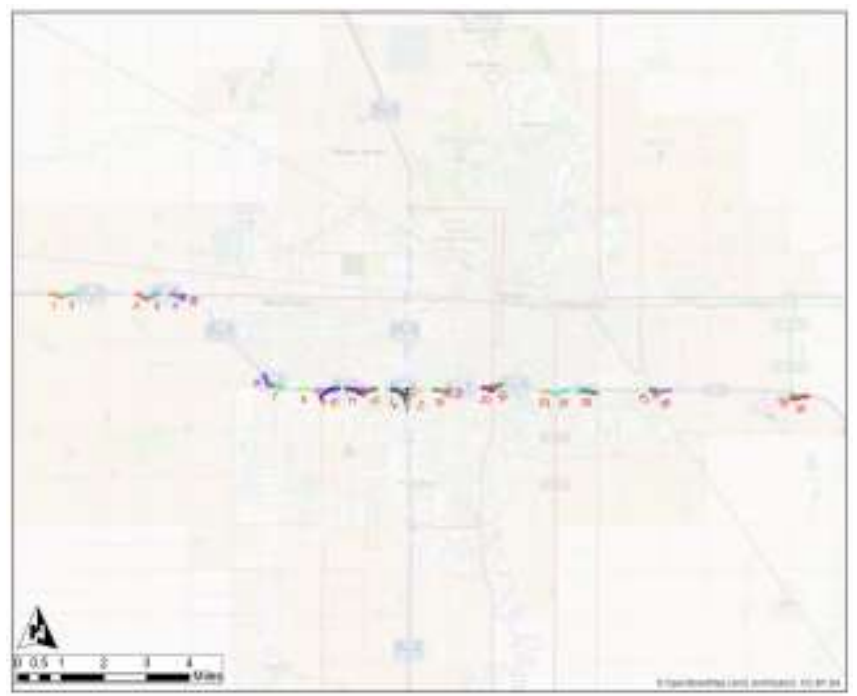

Fig -4: I-94 Ramp Locations 
Table -1: Details of Ramp Locations

\begin{tabular}{|c|c|c|c|c|}
\hline Type & SI & Locations & Segment Type & Segment Length \\
\hline Ramp & 1 & 165th Ave SE & Off-Ramp & 1477 \\
\hline Ramp & 2 & 165th Ave SE & On-Ramp & 1701 \\
\hline Ramp & 3 & 38th St NW & Off-Ramp & 1513 \\
\hline Ramp & 4 & 39th St NW & On-Ramp & 1441 \\
\hline Ramp & 5 & 26th St NW & Off-Ramp & 1716 \\
\hline Ramp & 26 & 26th St NW & On-Ramp & 946 \\
\hline Ramp & 6 & Sheyenne Street & Off-Ramp & 1605 \\
\hline Ramp & 7 & Sheyenne Street & On-Ramp & 1422 \\
\hline Ramp & 8 & 9th St E & Off-Ramp & 2854 \\
\hline Ramp & 9 & 9th St E & On-Ramp & 1027 \\
\hline Ramp & 10 & 9th St E & On-Ramp & 2592 \\
\hline Ramp & 11 & 45th St S & Off-Ramp & 2266 \\
\hline Ramp & 12 & 45th St S & On-Ramp & 1522 \\
\hline Ramp & 13 & 45th St S & On-Ramp & 1723 \\
\hline Ramp & 14 & I-29 & Off-Ramp & 2692 \\
\hline Ramp & 15 & I-29 & Off-Ramp & 1864 \\
\hline Ramp & 16 & $\mathrm{I}-29$ & On-Ramp & 1145 \\
\hline Ramp & 17 & I-29 & On-Ramp & 3049 \\
\hline Ramp & 18 & 25th St S & Off-Ramp & 2144 \\
\hline Ramp & 19 & 25th St S & On-Ramp & 873 \\
\hline Ramp & 20 & University Dr S & Off-Ramp & 1353 \\
\hline Ramp & 21 & University Dr S & On-Ramp & 1270 \\
\hline Ramp & 22 & University Dr S & On-Ramp & 1263 \\
\hline Ramp & 23 & 8th St S & Off-Ramp & 1151 \\
\hline Ramp & 24 & 8th St S & On-Ramp & 1679 \\
\hline Ramp & 25 & 20th St S & Off-Ramp & 1955 \\
\hline Ramp & 27 & 34th St S & Off-Ramp & 1560 \\
\hline Ramp & 28 & 34th St S & On-Ramp & 2199 \\
\hline Ramp & 29 & 70th St S & Off-Ramp & 1160 \\
\hline Ramp & 30 & 70th St S & On-Ramp & 2182 \\
\hline
\end{tabular}

\subsection{Model Selection}

Existing Travel Demand Model for the base year 2010 for the Fargo-Moorhead Metropolitan Planning Area was utilize for this study.

\subsection{Software Utilization}

Since the model were developed using Cube Voyager, different models and scenarios running have been performed inside the Cube Voyager. ArcGIS was utilized for geodatabase and shape file editing and mapping purposes. Besides this, spreadsheet and SAS language was used for data processing and statistical analysis.

\section{RESULTS AND DISCUSSIONS}

\subsection{Link Performance}

The estimated volume-to-capacity ratio matrix presented in Table 2 and Figures 5 and 6 indicated that seven out of 33 segments with a v/c ratio greater than 1.0. A total of 12 segments with a v/c ratio greater than 0.90 . The interstate I94 eastbound is globally oversaturated. All this 12 segments are situated in the urban area.
Table -2: Segmented Performance Conditions

\begin{tabular}{ccccc}
\hline Segment & Lanes & V/C & LOS HCM 2010 & LOS HCM 2000 \\
\hline 6 & 2 & 0.50 & $\mathrm{~B}$ & $\mathrm{~B}$ \\
7 & 2 & 0.58 & $\mathrm{~B}$ & $\mathrm{~B}$ \\
8 & 2 & 0.54 & $\mathrm{~B}$ & $\mathrm{~B}$ \\
9 & 2 & 0.65 & $\mathrm{~B}$ & $\mathrm{~B}$ \\
10 & 2 & 0.59 & $\mathrm{C}$ & $\mathrm{B}$ \\
11 & 2 & 1.05 & $\mathrm{D}$ & $\mathrm{D}$ \\
12 & 2 & 1.29 & $\mathrm{C}$ & $\mathrm{E}$ \\
13 & 2 & 1.13 & $\mathrm{C}$ & $\mathrm{D}$ \\
14 & 3 & 0.99 & $\mathrm{C}$ & $\mathrm{D}$ \\
15 & 3 & 1.09 & $\mathrm{C}$ & $\mathrm{D}$ \\
16 & 3 & 0.98 & $\mathrm{C}$ & $\mathrm{D}$ \\
17 & 2 & 0.98 & $\mathrm{D}$ & $\mathrm{B}$ \\
18 & 3 & 1.48 & $\mathrm{C}$ & $\mathrm{F}$ \\
19 & 3 & 0.98 & $\mathrm{C}$ & $\mathrm{D}$ \\
20 & 3 & 1.08 & $\mathrm{C}$ & $\mathrm{D}$ \\
21 & 3 & 1.08 & $\mathrm{C}$ & $\mathrm{D}$ \\
22 & 3 & 0.84 & $\mathrm{C}$ & $\mathrm{C}$ \\
23 & 3 & 0.88 & $\mathrm{C}$ & $\mathrm{C}$ \\
24 & 3 & 0.93 & $\mathrm{~B}$ & $\mathrm{C}$ \\
25 & 2 & 0.79 & $\mathrm{~B}$ & $\mathrm{C}$ \\
26 & 2 & 0.82 & $\mathrm{~A}$ & $\mathrm{C}$ \\
27 & 2 & 0.73 & $\mathrm{~B}$ & $\mathrm{~B}$ \\
28 & 2 & 0.73 & $\mathrm{~B}$ & $\mathrm{C}$ \\
29 & 2 & 0.73 & $\mathrm{~A}$ & $\mathrm{C}$ \\
30 & 2 & 0.43 & $\mathrm{~B}$ & $\mathrm{C}$ \\
31 & 2 & 0.47 & $\mathrm{~A}$ & $\mathrm{~B}$ \\
32 & 2 & 0.27 & $\mathrm{~A}$ & $\mathrm{~A}$ \\
33 & 2 & 0.29 & $\mathrm{~A}$ & \\
\hline & & & & \\
\hline
\end{tabular}

It can be inferred that in the central part of interstate v/c capacity is increasing, i.e., the central part of interstate is deficient against the current capacity. From $9^{\text {th }}$ street $\mathrm{E}$ to $34^{\text {th }}$ street $\mathrm{S}$ are experiencing more traffic and showing deficiency in volume capacity ration.

Segment wide level of service was measured based on highway capacity software, which used highway capacity manual 2000. Segment wide level of service was also measured based on highway capacity manual 2010. Both of these results have been presented in Table 2 and Figure 6. Both the manuals produced similar results except in the central part. Since in the planning purpose, level of service C and D both are acceptable. Thus, based on HCM 2010, interstate I-94 eastbound has acceptable level of service. However, based on HCM 2000, two segments between $9^{\text {th }}$ street $\mathrm{E}$ and $45^{\text {th }}$ street $\mathrm{S}$, and between I-29 and $25^{\text {th }}$ Street $\mathrm{S}$ were having $\mathrm{E}$ and $\mathrm{F}$ level of services, which indicated deficiency in level of services.

In order to achieve a target or goal level of services $C$ for both of this segment, a new lane may require to between $9^{\text {th }}$ street $\mathrm{E}$ and $45^{\text {th }}$ street. Two new lanes need to be added between I-29 to $25^{\text {th }}$ street $\mathrm{S}$ to achieve a level of service C. 


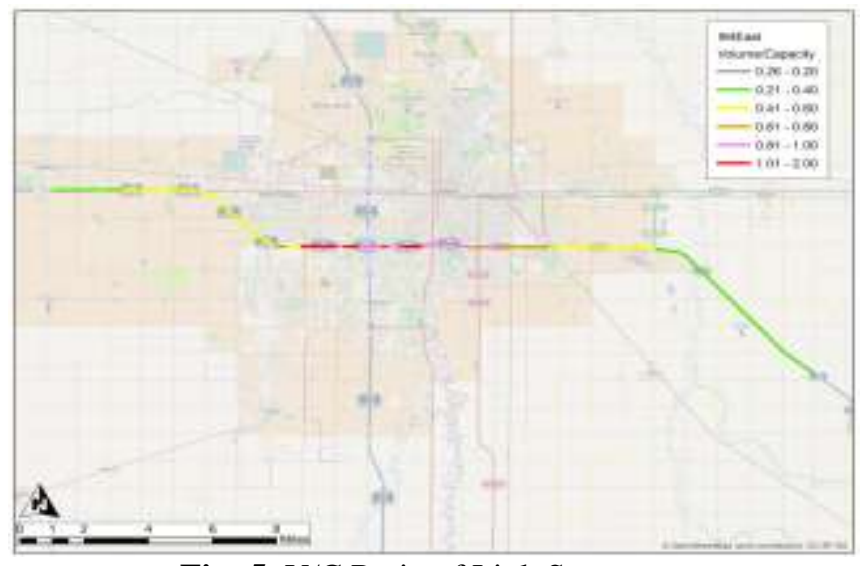

Fig -5: V/C Ratio of Link Segments

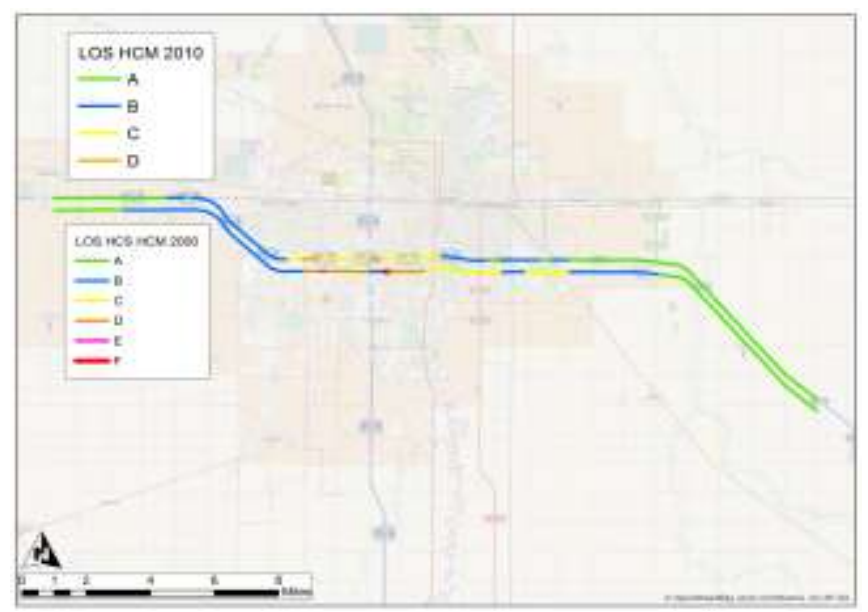

Fig -6: Level of Service on I-94 Eastbound

\subsection{Ramp Performance}

Even though I-94 eastbound link segments is showing pretty good level of services, however, 13 interchanges along the eastbound are showing severely deficiency in level of service in the central part of the metropolitan planning area. Volume to capacity and level of service is presented in Table 3. More details of each interchanges is included in Appendix A.1.

It was revealed that five ramps located (on-ramp in $9^{\text {th }} \mathrm{St} \mathrm{E}$, off-ramp I-29, on-ramp I-29, $25^{\text {th }}$ St S off-ramp, and $8^{\text {th }}$ Street $\mathrm{S}$ off-ramp) is having severe volume to capacity ratio, which was more than 1.0. Based on HCM 2010, four ramps (off-ramp I-29, on-ramp I-29, $25^{\text {th }}$ St S off-ramp, and $8^{\text {th }}$ Street $\mathrm{S}$ off-ramps) are having level of service $\mathrm{F}$ and onramp in $9^{\text {th }} \mathrm{St} \mathrm{E}$ are having level of service E. Since majority of the ramp from $9^{\text {th }} \mathrm{St} \mathrm{E}$ to University Dr. S is deficient in level of service, which has the similar case in link segment, therefore, special focus is necessary for the deficient ramp and areas. There are many ways the better level of service of ramp could be attained. Here, addition of lanes approach was considered. Adding one more lane on ramp segment number 9 to 19 except ramp segment number 16 where two more lanes requires defined in Table 3 may facilitate to attain a desired level of service $\mathrm{C}$.
Table -3: Performance of Interchanges

\begin{tabular}{ccccccc}
\hline Segment & Locations & Segment Type & V/C & LOS HCM 2010 & LOS HCM 2000 \\
\hline 1 & 165th Ave SE & Off-Ramp & 0.07 & A & A \\
2 & 165th Ave SE & On-Ramp & 0.40 & B & B \\
3 & 38th St NW & Off-Ramp & 0.02 & A & B \\
4 & 39th St NW & On-Ramp & 0.23 & A & B \\
5 & 26 th St NW & Off-Ramp & 0.03 & A & B \\
26 & 26th St NW & On-Ramp & 0.11 & A & B \\
6 & Sheyenne Street & Off-Ramp & 0.09 & A & B \\
7 & Sheyenne Street & On-Ramp & 0.25 & A & C \\
8 & 9 th St E & Off-Ramp & 0.15 & A & B \\
9 & 9 th St E & On-Ramp & 1.05 & E & F \\
10 & 9 th St E & On-Ramp & 0.55 & C & F \\
11 & 45 th St S & Off-Ramp & 0.36 & B & D \\
12 & 45 th St S & On-Ramp & 0.80 & D & E \\
13 & 45 th St S & On-Ramp & 0.35 & B & D \\
14 & I-29 & Off-Ramp & 0.37 & B & D \\
15 & I-29 & Off-Ramp & 1.12 & F & D \\
16 & I-29 & On-Ramp & 2.06 & F & D \\
17 & I-29 & On-Ramp & 0.75 & D & F \\
18 & 25 th St S & Off-Ramp & 1.71 & F & E \\
19 & 25 th St S & On-Ramp & 0.34 & B & F \\
20 & University Dr S & Off-Ramp & 0.79 & D & D \\
21 & University Dr S & On-Ramp & 0.12 & A & D \\
22 & University Dr S & On-Ramp & 0.18 & A & C \\
23 & 8th St S & Off-Ramp & 1.37 & F & C \\
24 & 8th St S & On-Ramp & 0.07 & A & F \\
25 & 20 th St S & Off-Ramp & 0.21 & A & B & B \\
27 & 34 th St S & Off-Ramp & 0.68 & D & B \\
\hline & 34 th St S & On-Ramp & 0.09 & A & C \\
\hline
\end{tabular}

The results revealed deficiencies of interstate I-94 eastbound with respect to volume capacity ratio and level of services. It can be concluded that the findings of the study indicated potential problems of existing condition of interstate facilities, which need to be under consideration seriously in order to avoid the congestion. The result also reveals significant difference in Highway Capacity Manual 2000 and 2010 in producing level of service measures.

\section{CONCLUSIONS}

This study compared the implications of highway capacity manual 2010 and 2000 on measuring freeway level of service and volume-capacity ratio. The study revealed dissimilarity between the year 2000 and 2010. The study presents a case study based on planning model approach. However, the results could be useful to make suitable transportation planning and decision making on freeway. Road segment can be further divided into smaller pieces so that details analysis would revealed better results.

\section{REFERENCES}

[1] Fargo-Moorhead Metropolitan Council of Governments. (2014). 2014 Long Range Transporation Plan. Fargo, ND.

[2] Federal Highway Administration. (2015, 3 26). Highway Functional Classification: Concepts, Criteira 
and Procedures. Retrieved from http://www.fhwa.dot.gov/planning/processes/statewide/ related/highway_functional_classifications/fcauab.pdf

[3] Transportation Research Board. (2000). Highway Capacity Manual 2000. Washington, D.C.

[4] Transportation Research Board. (2007). Metropolitan Travel Forecasting. Washington, D.C.

[5] Transportation Research Board. (2010). Highway Capacity Manual. Washinton, D.C.

[6] Transportation Research Board. (2012). Travel Demand Forecasting: Parameteres and Techniques, NCHRP Report 716. Washington, D.C.

[7] Ulteigh and McKibben Demographics Research. (2012). Demographic Forecast Study for the FM Metropolitan Area. FArgo, ND. Retrieved 3 26, 2015, from

http://www.fmmetrocog.org/new/assets/documents/Ma ps/2012\%20Demographic\%20Forecast\%20Final\%20Re port_Approved.pdf

\section{APPENDIX A}

\section{A.1. I-94 Eastbound Interchange Details}

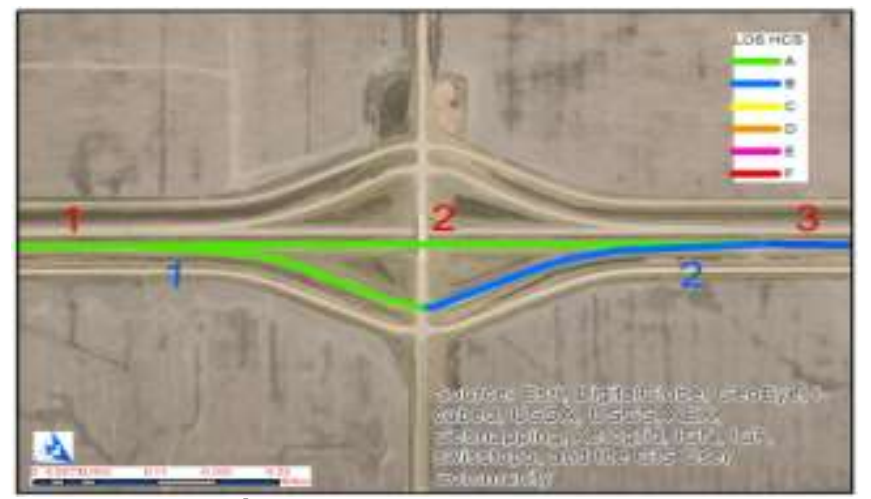

Location: $165^{\text {th }}$ Ave SE

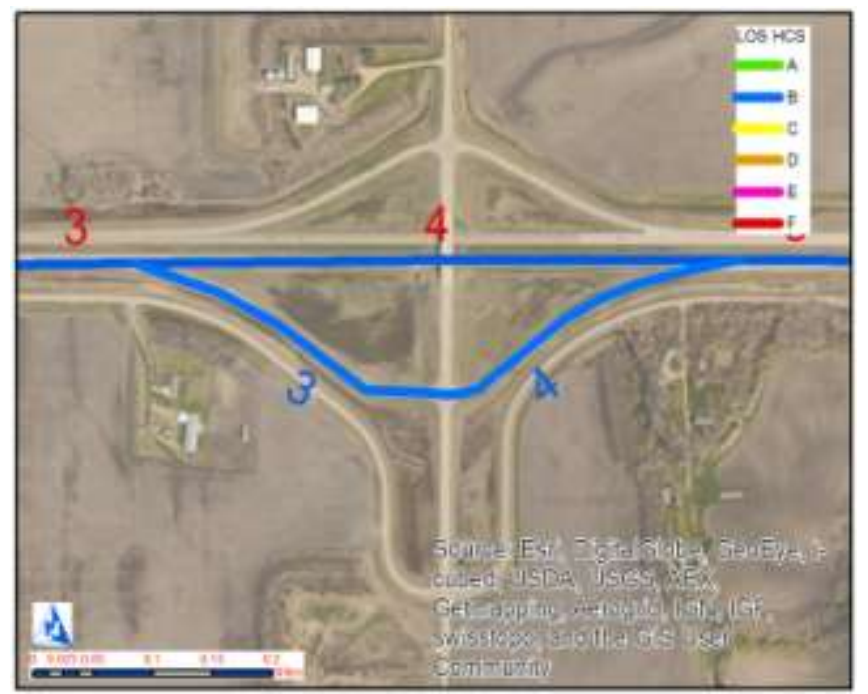

Location: $38^{\text {th }}$ Street NW

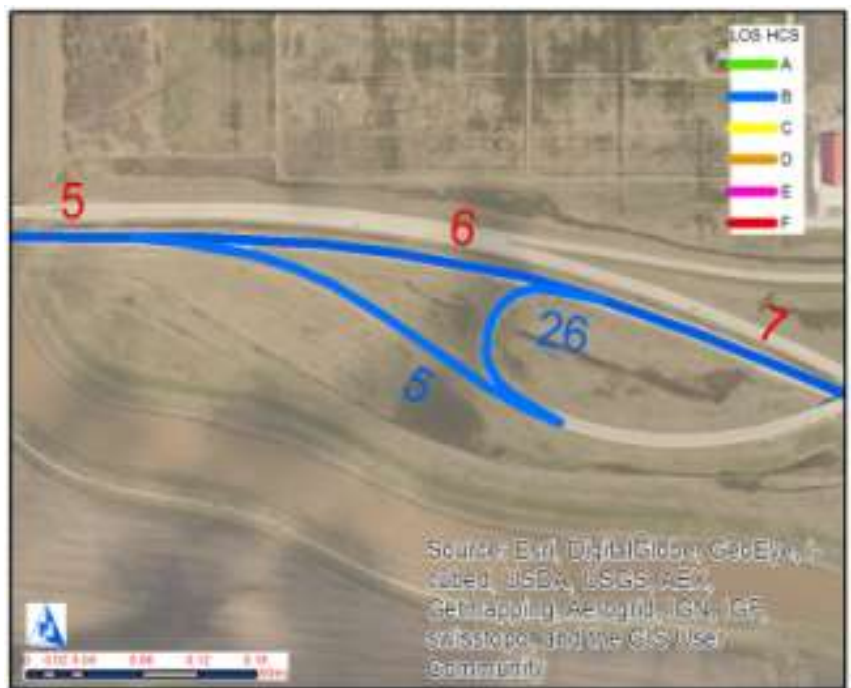

Location: 26 $^{\text {th }}$ Street NW

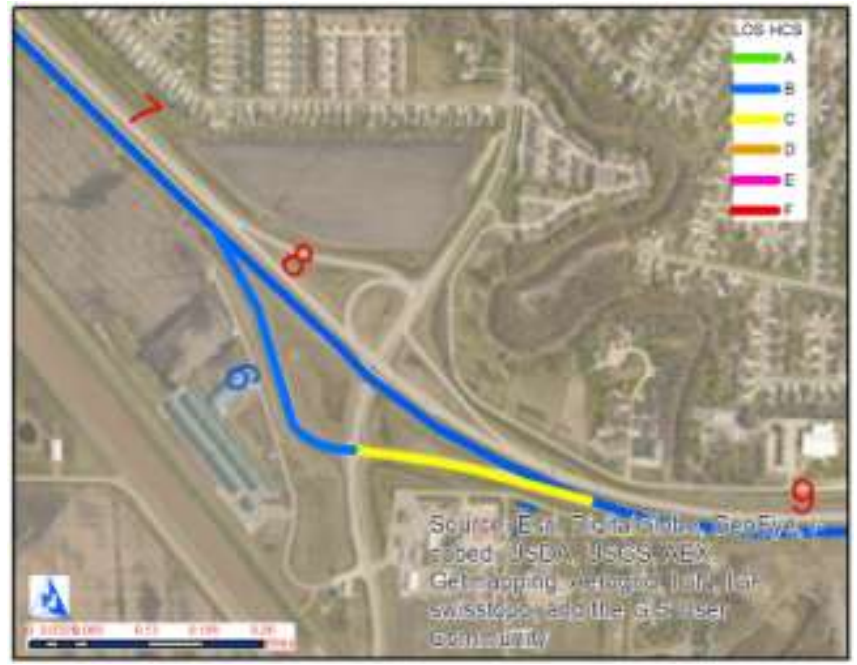

Location: Sheyenne Street

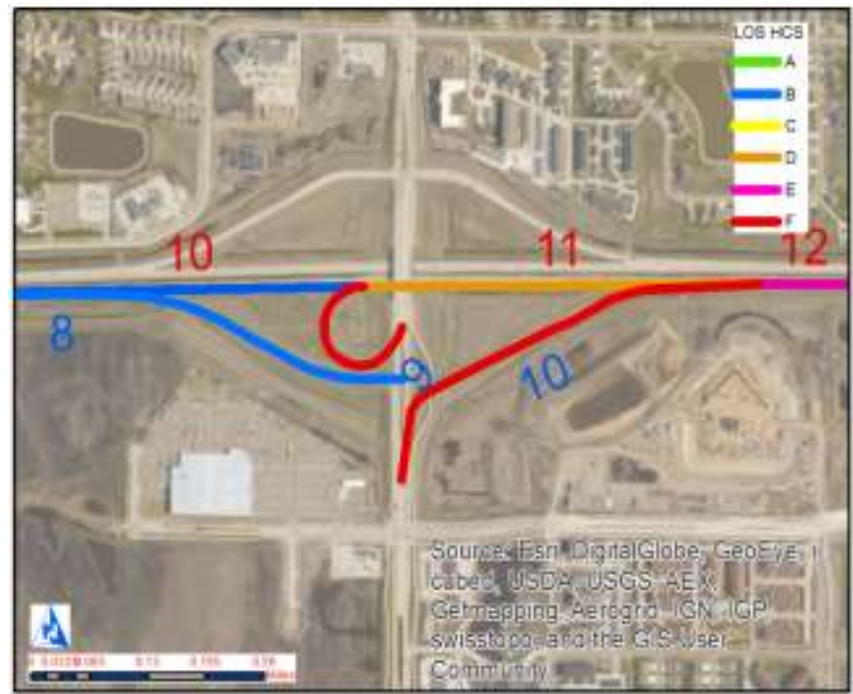

Location: 9th Street E 


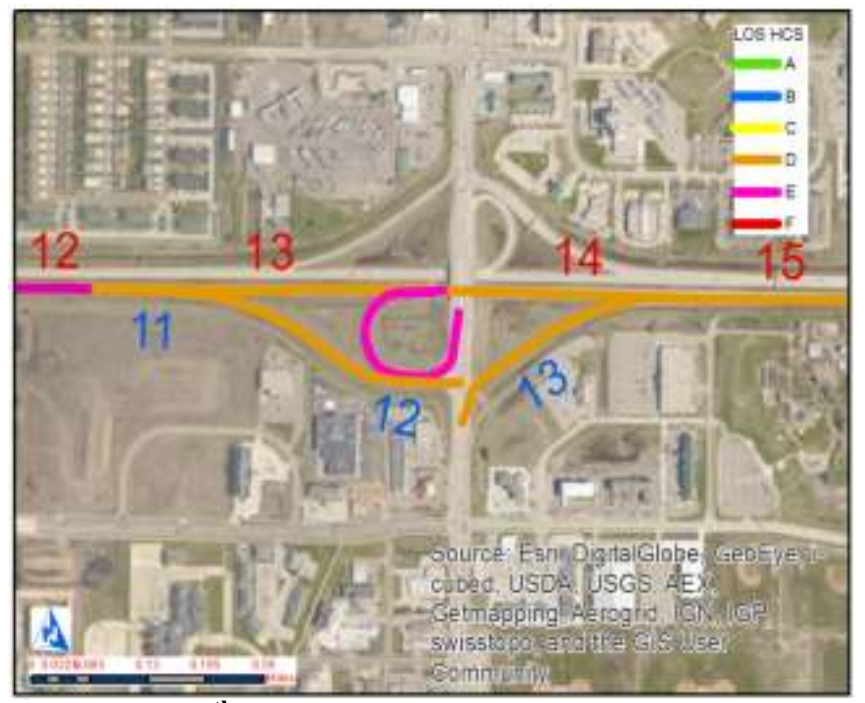

\section{Location: $\mathbf{4 5}^{\text {th }}$ Street $S$}

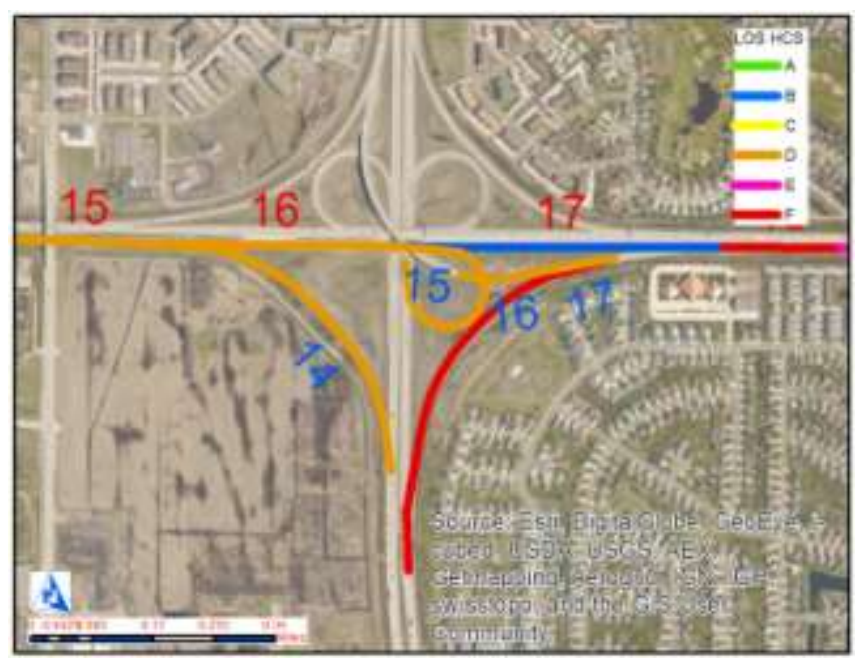

\section{Location: I-29}

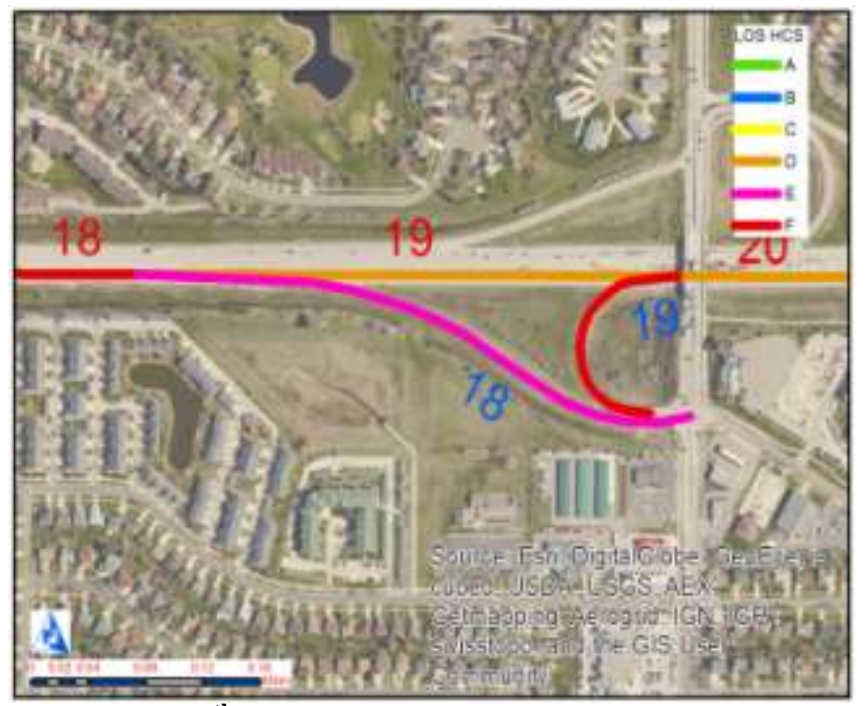

Location: $\mathbf{2 5}^{\text {th }}$ Street $\mathrm{S}$

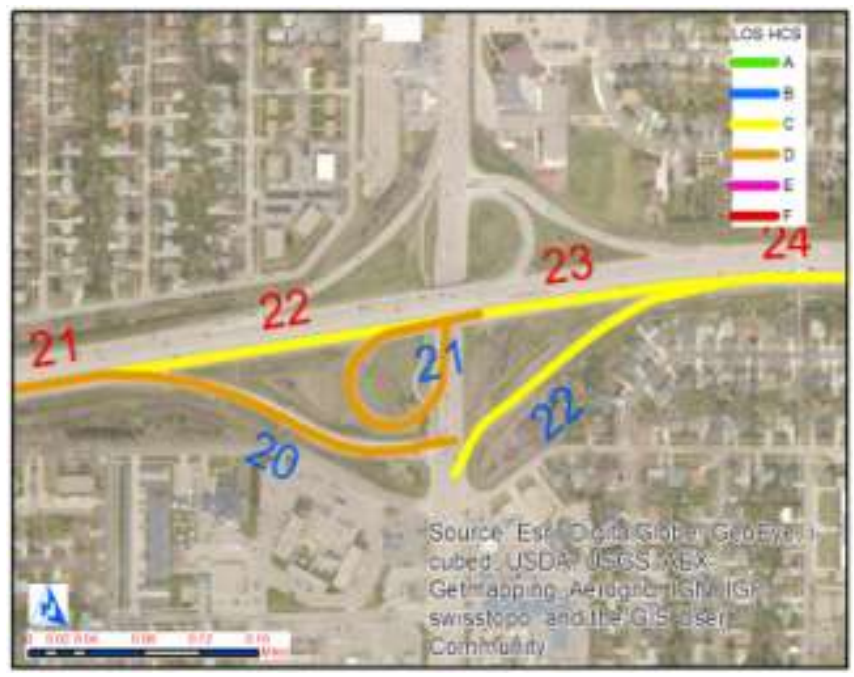

Location: University Dr S

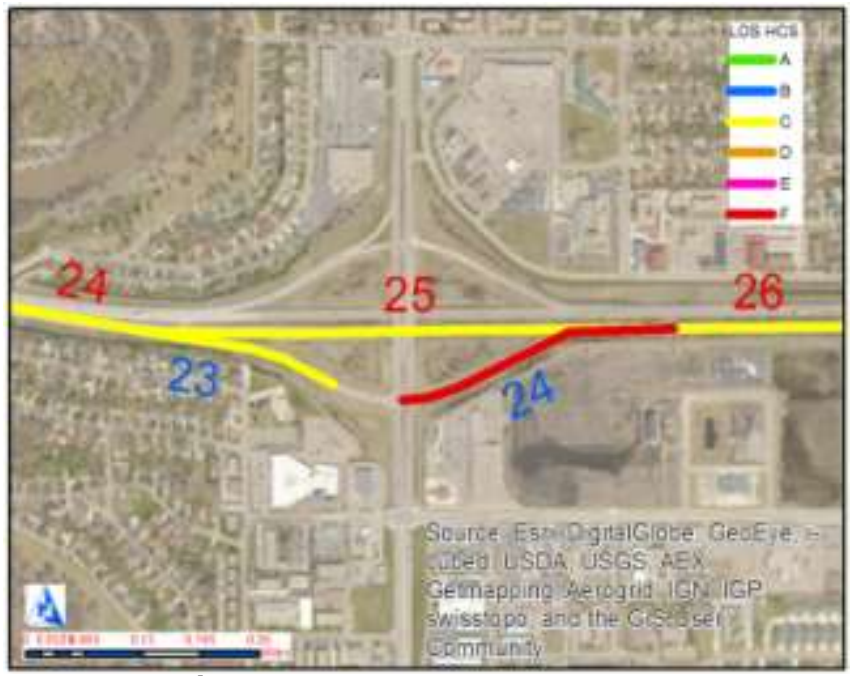

\section{Location: $8^{\text {th }}$ Street $S$}

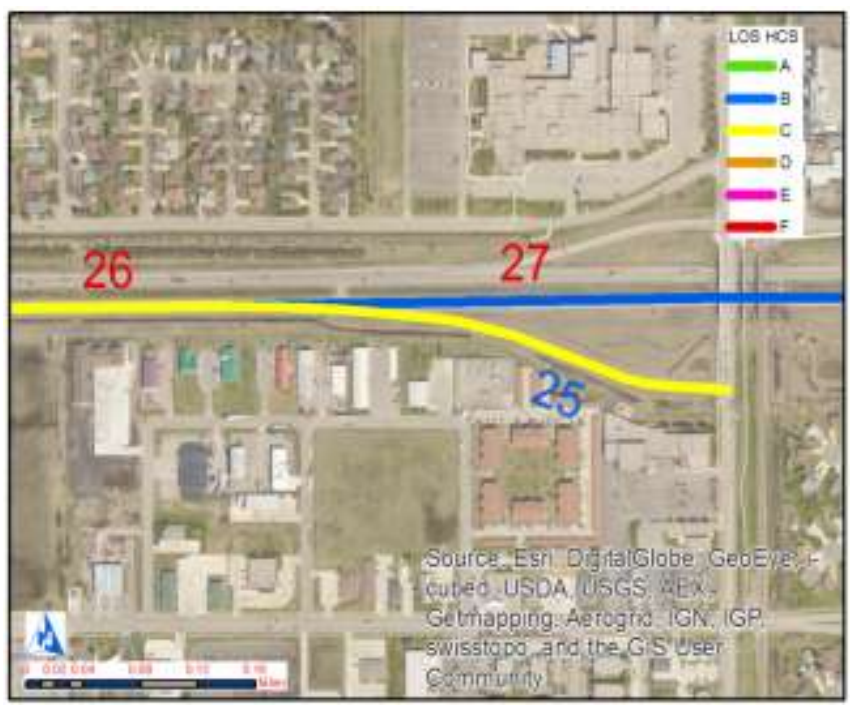

Location: $20^{\text {th }}$ Street $S$ 


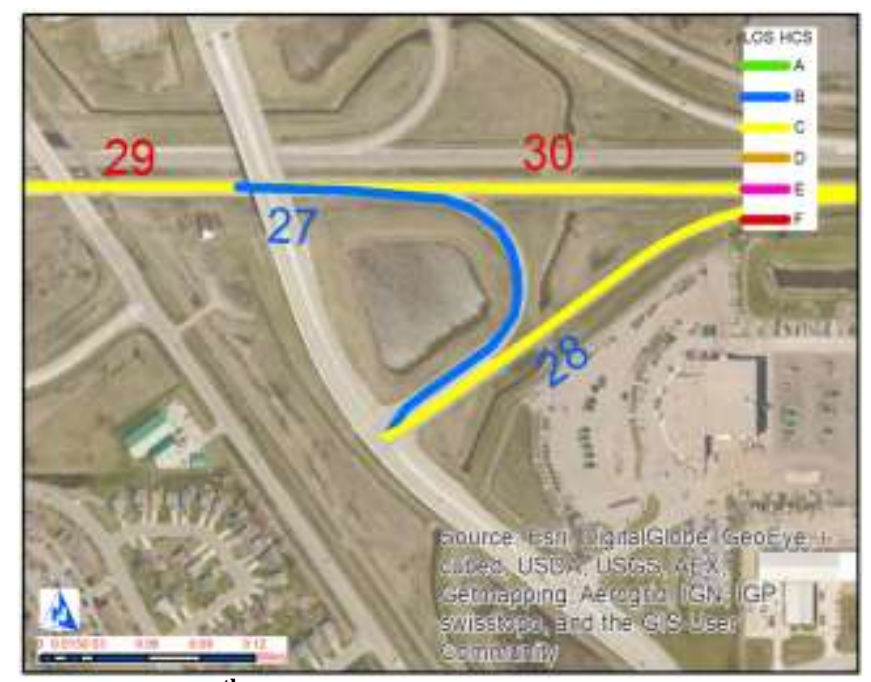

Location: $34^{\text {th }}$ Street $\mathrm{S}$

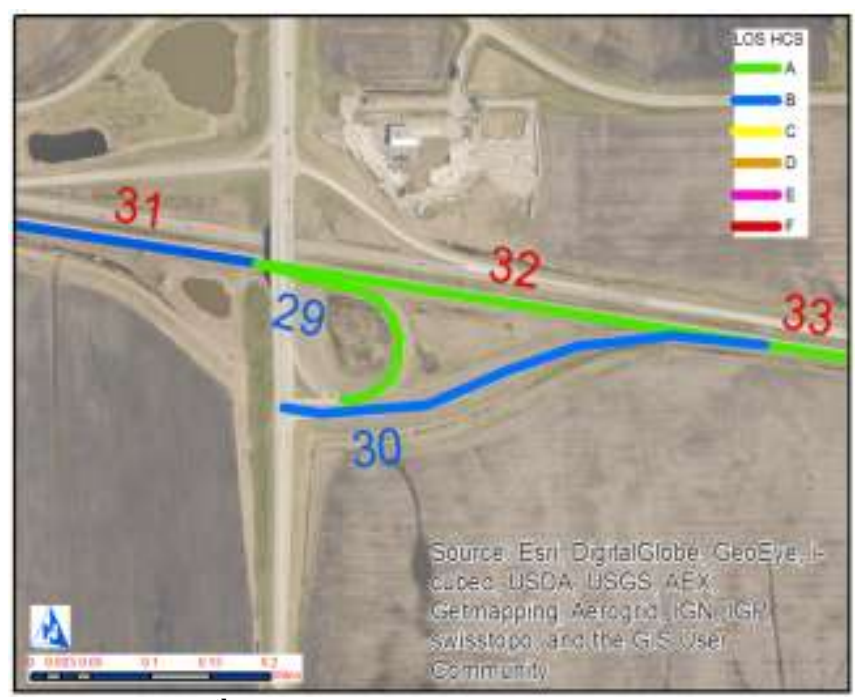

Location: 70 $^{\text {th }}$ Street $S$ 